7. There should be a specific offence of wilful neglect and ill-treatment on the lines of section 83 of the Incapacity (Scotland) Act 2000, or section 1 of the Children and Young Persons Act 1933.

8. The Court of Protection should have the power to require the Official Solicitor to prepare a welfare report on an IP for the Court (the cost of preparing which should fall upon the Official Solicitor's budget).

\section{P M Harris}

Chairman of the Family Law Working Group

The members of the Working Group who contributed to the deliberations of the Working Party on Decision making for Incapacitated Adults were:

P.M. Harris, chairman; Ms Barbara Beaton, Age Concern; Ms N Finch, barrister; Mr Francis QC; Ms Liz. Humphreys, Lord Chancellor's Department; Mrs Claire Johnston, Official Solicitor's Office; Ms. Nicola Mackintosh, Mackintosh Duncan; The Hon Mrs C Renton, barrister; Dr S Sa'eed; Ms A Sogan; Mr Malcolm Thompson

\title{
The effects of the Human
}

\section{Rights Act 1998 on arbitration}

\author{
by William Robinson
}

The Human Rights Act 1998 (Act) gives 'further effect' to certain rights and freedoms guaranteed under the European Convention on Human Rights (Convention). The Lord Chancellor described the aim of the legislation as enabling 'people ... to argue for their rights and claim their remedies under the Convention in any court or tribunal in the United Kingdom.' The issues under consideration in (582 HL Official Report (5th Series), col.1228 (3 November 1997) paper are whether the Act affects commercial arbitration and, if so, to what practical extent.

\section{RELEVANT PROVISIONS OF THE CONVENTION AND THE ACT}

Whilst certain substantive Convention rights may arise in commercial arbitration, for example, the right to respect for private and family life, home and correspondence (Art. 8), freedom of expression (Art. 10) and the right to property (Art. 1 of the First Protocol) it is the procedural rights enshrined in Art. 6(1) of the Convention that are likely to arise most frequently, and which will be considered in this paper. Article 6(1) provides:

'In the determination of his civil rights and obligations or of any criminal charge against him, everyone is entitled to a fair and public hearing within a reasonable time by an

independent and impartial tribunal established by law.'

As to the Act, a number of difficult points of interpretation arise. For the purposes of this paper, it is sufficient to identify three core provisions that are relevant to the central question of the potential application of the Act to arbitration.

First, section 1 of the Act identifies the articles of the Convention that are to 'have effect for the purposes of this Act'. As to the interpretation of Convention rights, 'a court or tribunal' must take account of the rulings of the Strasbourg institutions consisting of the European Court of Human Rights (the court), the Commission on Human Rights (the Commission) and the Committee of Ministers. 'Tribunal' is defined in section $21(1)$ as 'any tribunal in which legal proceedings may be brought'.

Second, section 3 of the Act requires that, "so far as it is possible to do so, primary and subordinate legislation must be read and given effect in a way which is compatible with Convention rights.' This rule of interpretation does not affect the validity of primary (and certain subordinate) legislation. 
Third, specific obligations are placed on 'public authorities'. Section 6(1) of the Act provides that, 'It is unlawful for a public authority to act in a way which is incompatible with a Convention right'. 'Public authority' includes '(a) a court or tribunal, and (b) any person certain of whose functions are functions of a public nature...' (see section 6(3)).

\section{VOLUNTARY AND COMPULSORY ARBITRATION}

In Bramelid and Malmström v Sweden (1982) DR 64, EcomHR Application 8588/79 the Commission drew a distinction between compulsory and voluntary arbitration:

'[a] distinction must be drawn between voluntary arbitration and compulsory arbitration. Normally Article 6 poses no problem where arbitration is entered into voluntarily ... If, on the other hand, arbitration is compulsory in the sense of being required by law ... the parties have no option but to refer their dispute to an arbitration Board, and the Board must offer the guarantees set forth in Article 6(1).'

\section{COMPULSORY ARBITRATION}

The application of the Convention and the Act to compulsory arbitration can be dealt with briefly. Indeed, in Scarth $v$ United Kingdom EcomHR Application 33745/96, judgment dated 22 July 1999 (unreported), the United Kingdom Government admitted, and the Court found, a breach of Article 6(1) of the Convention in circumstances where an arbitrator appointed in accordance with compulsory arbitration under the County Court Rules refused to hear the matter in public. Accordingly, the Act applies to compulsory arbitration, by virtue of section 6 of the Act, as either a 'tribunal' in which legal proceedings must be brought and/or a public authority whose functions are of a public nature.

Nevertheless, the application of the Act and Article 6(1) to compulsory arbitrations need not necessarily require that each and every guarantee provided by that Article must be adhered to in each case. Two derogations are possible. First, parties to compulsory arbitration may voluntarily waive their Article 6(1) rights. Second, if the compulsory arbitration procedures breach the guarantees enshrined in Article 6(1), such breaches may be 'cured' if a right of appeal exists (which need not be exercised) to a court or tribunal with competence to hear a full de novo appeal on all issues of fact and law. In Albert \& Le Compt $v$ Belgium (1983) EHRR 533, para.29, the ability of an appeal to 'cure' any Article 6(1) defects in the compulsory arbitration must be evaluated having regard to all the circumstances of the case and the statutory procedures. These issues arise, and will be considered in more detail, in respect of voluntary arbitration.

\section{VOLUNTARY ARBITRATION}

In respect of voluntary commercial arbitration, two issues arise: (i) does the Act apply, whether directly or indirectly, to commercial arbitration; and (ii) if so, may parties waive their rights under Article 6(1), how may a waiver be given and to what extent?

\section{Does the Act apply to Commercial Arbitration?}

The Act may apply to commercial arbitration by a variety of means. Three arguments are addressed below.

The first argument, which has found some support in the literature, suggests that voluntary arbitration is a 'public authority' within section 6 of the Act as either a 'tribunal' or as exercising 'functions of a public nature'. (See Ambrose, Arbitration and the Human Rights Act LMCLQ 2000, 4 (Nov), 468-494. If correct, arbitrators would be required to apply Article 6(1) directly (subject to issues of waiver, discussed below). The direct application of the Act is certainly true of compulsory arbitration. In Lithgow and Others $v$ United Kingdom (1986) 8 EHRR 329 (Judgment dated 8 July 1986, para. 201) in which the court held that a statutory arbitration procedure laid down under the Aircraft and Shipbuilding Industries Act 1977 fell within Article 6(1). The Government acknowledged during the passage of the Human Rights Bill that immigration; housing and employment tribunals would fall within section 6 . There are, however, numerous and persuasive reasons why this argument is flawed in respect of voluntary arbitration.

- The definition of 'tribunal' is implicitly linked to the exercise of 'functions of a public nature'. For example, the Lord Advocate's reasoning as to why Church of Scotland courts would not constitute 'tribunals' within the Act relied upon the private nature of the process and the absence of the exercise of judicial functions on behalf of the state.

- It is clear that judicial review, the 'most valuable asset' in defining "public authority", (Jack Straw MP (17 June 1998) 314 HC Official Report (6th Series) col. 409) is not available in respect of voluntary arbitration.

- The Court has, as seen above, distinguished between compulsory and voluntary arbitration. The Convention's unwillingness to hold a state responsible for voluntary arbitration is demonstrated in $R \quad V$ Switzerland (1987) 51 DR 83. The arbitrators in question had taken over seven years to reach their decision (the national court reached a decision on appeal within nine months). $\mathrm{R}$ complained that the arbitrators' delay breached the Article 6(1) right to a decision within a reasonable time. The Commission found that, having regard to the nature of the voluntary arbitration, "the State cannot be held responsible for the arbitrators' actions unless, and only insofar as, the national courts were required to intervene.' As the 
courts had dealt with the matter expeditiously, the complaint was dismissed. The time taken before the voluntary arbitration was implicitly ignored for the evaluation of Article 6(1).

- The Court of Justice of the European Communities has not recognised voluntary arbitration as an organ of the State. As such, an arbitral tribunal is not a 'tribunal' within Article 234 EC capable of making a reference for a preliminary ruling Case 102/81, Nordsee [1982] ECR 1095.

- As to the definition of 'tribunal' in section 21 of the Act, it must be doubted whether arbitral proceedings are 'legal proceedings' and also whether voluntary arbitration is a tribunal 'in which legal proceedings may be brought' (emphasis added). In these circumstances, it is unlikely that voluntary arbitration falls within section 6 of the Act. See, by analogy, Austin Hall Building Ltd v Buckland Securities Ltd [2001] BLR 272, TCC, in which Bowsher J held that an 'adjudicator' in a construction claim was not a 'tribunal under the Act. This conclusion preserves the flexibility that parties chose by virtue of arbitration.

The second argument relies upon the duty of arbitrators to apply English law, where so chosen. That duty flows from the Arbitration Act 1996, section 46(1), and common law in President of India $v$ La Pintada CNSA [1985] AC 104; Wealands v CLC Contractors Ltd [1999] 2 Lloyd's Rep 739. Even if the Convention was not incorporated into English law in the manner traditional for public international law instruments, both the purpose of the Act and the wording of section 1(2) make plain that the identified Convention rights are to 'have effect' in English law. That effect is crystallised in the interpretative obligation set out in section 3 , the breadth of which has been recognised most recently by the House of Lords in $R$ v A [2001] UKHL 25, e.g. per Lord Steyn, paragraph 44. Indeed, it may be argued that the Act's Convention rights now form part of English public policy. See, by analogy, Case C-7/98, Krombach, judgment of 28 March 2000 (not yet reported) in which the Court of Justice of the European Communities held that Convention rights constituted 'public policy' reasons which a Member State may invoke to refuse recognition and enforcement of judgments under the Brussels Convention. Arbitrators are under an obligation to apply English law, including the Act, by reason of such general principles.

This argument is supported by the provisions of the Arbitration Act 1996 that provide, notably, recognition and enforceability of arbitral awards, immunity from suit upon arbitrators acting in their judicial role and an application to the Commercial Court on grounds of error of law and serious procedural irregularity. Sections 66, 74 and 68 and 69 of the Arbitration Act 1996, respectively.

Reliance on the Arbitration Act 1996 leads to a third argument regarding the application of the Act to voluntary arbitration. As arbitral awards may be recognised and enforced by the Commercial Court, and appeals lodged with that court, the issue arises as to whether the Commercial Court may enforce or sanction an award engendering a breach of the Act, or reach otherwise than in conformity with Article 6(1). It is arguable that the Commercial Court's obligation not to act incompatibly with Convention rights precludes the enforcement or sanctioning of awards that contain breaches of those rights or was reached in breach of the Act. There is significant force in this argument, although it must be nuance in light of the case law of the Strasbourg Court.

According to Convention case-law, the manner of application of Article 6 to proceedings before appeal courts depends on the special features of the proceedings involved; account must be taken of the proceedings as a whole and of the role of the appellate court, Axen v Germany (1984) 6 EHRR 195. The Commission considered the exercise of appellate functions over arbitration awards in Nordström-Janzon (1996) 87 DR 112, EcomHR Application 28101/95, decision 27 November 1996.

In that case, an arbitral tribunal rendered an award pursuant to arbitration proceedings regarding the interpretation of a joint-venture agreement. The applicant sought to quash the award on the ground that there was an alleged appearance of impartiality of one of the arbitrators. The Dutch courts rejected that application as they considered that there were no objectively justified reasons for questioning the independence and impartiality of the arbitrator. The Commission's decision to reject the complaint of a breach of Article 6(1) is grounded in the waiver of those rights by virtue of the agreement to arbitrate. As to the control of arbitration proceedings exercised by the courts, the Commission noted that:

'Dutch law contains rules which permit the courts to quash arbitral awards on specific grounds.

and found that:
'it cannot be required under the Convention that national courts must ensure that arbitral proceedings have been in conformity with Article 6 of the Convention. In some respects - in particular as regards publicity - it is clear that arbitral proceedings are often not even intended to be in conformity with Article 6, and the arbitration agreement entails a renunciation of the full application of that Article. The Commission therefore considers that an arbitral award does not necessarily have to be quashed because the parties have not enjoyed all the guarantees of Article 6 (Art. 6), but each Contracting State may in principle decide itself on which grounds an arbitral award should be quashed.

Accordingly, the limited review by Dutch courts on grounds of public order interests and the necessity for strong reasons for quashing an award were in conformity with the Convention. The Commission recognised both the practical and policy requirement to limit the review of arbitral awards. 
An appeal from an arbitral award and human rights considerations were examined by the Commercial Court in Mousaka Inc ${ }_{v}$ Golden Seagull Maritime Inc and others, Judgment dated 20 July 2001, Steel J (unreported). Mr Justice Steel was requested to provide reasons (as allegedly required in those circumstances by Article 6(1)) for a decision not to permit an application under section 69 of the Arbitration Act 1996. He had regard to the nature of the arbitration proceedings and heard argument as to the Convention's requirements for appellate courts to give reasons on permission decisions, Webb $v$ United Kingdom (1997) 24 EHRR CD 73. Mr Justice Steel held that the Commercial Court was not required to give reasons. He found that decision to be consistent with the Convention and Nordström-Janzon. Whilst it is not stated in the judgment that the court regarded itself as bound by the Act in these circumstances, there can be no reason for the examination of the Convention issues if it did not recognise that it was bound. Accordingly, Mousaka supports the proposition that the Commercial Court is bound by the Act when considering applications under the Arbitration Act.

In light of these three arguments, it should be concluded that voluntary arbitration is subject indirectly to the Act by virtue of (i) the general duty on arbitrators to apply English law and (ii) the obligation of the Commercial Court under the Act to apply Convention rights albeit to the extent required of an appellate court.

The conclusion that arbitral proceedings should be conducted in accordance with the Act applies irrespective of the nature of the parties to the arbitration, namely private parties or public authorities. The tribunal must observe compliant procedures and adopt an interpretation of the law in conformity, so far as possible, with the Act. This accords to the practice of the courts since the entry into force of the Act. See, for example, Douglas and Others $v$ Hello! [2001] 2 All ER 289, in which the court of Appeal whilst avoiding the need to decide the issue - recognised the requirement of the Act that the courts must themselves act compatibly with Convention rights in determining disputes between private parties (notably per Sedley LJ). This approach circumvents many of the issues of the 'horizontal' application of the Act that were discussed with fortitude at the time of entry into force of the Act.

\section{Waiver: the agreement to arbitrate}

The analysis above relies upon the notion of waiver of Convention rights. An agreement between parties to arbitrate a dispute precludes, or limits, voluntarily those parties' right of access to the courts and the determination of that dispute in accordance with the court's procedures. Whilst the right of access to a court is a right that has been implied into Article 6 of the Convention, the Court has acknowledged the right of parties voluntarily to waive that right:

'In the Contracting States' domestic legal systems a waiver... is frequently encountered ... in civil matters, notably in the shape of arbitration clauses in contracts ... The waiver, which has undeniable advantages for the individual concerned as well as for the administration of justice, does not in principle offend against the Convention.' See Deweer v Belgium (1980) 2 EHRR 249, judgment dated 27 February 1980, para. 49 (a criminal case). (See also R v Switzerland (1987) 51 DR 83, EcomHR Application 10881/84, 1987 and X v Germany, Application 1197/61.)

Whilst not every substantive Convention right can be waived, where rights can be waived - such as Article 6(1) rights - the Court has stipulated three requirements for a valid waiver: (i) it must be unequivocal; Oberschlick v Austria (1991) 19 EHRR 389; (ii) it must not conflict with an important public interest; Hakansson and Struresson v Sweden (1991 13 EHRR 1 and (iii) it must be attended by minimum guarantees commensurate with the importance of the right waived; De Wilde Ooms and Versyp v Belgium (No.2) (1971) 1 EHRR 373; (1972) 1 EHRR 438. Further, the waiver cannot be given under duress. Accordingly, once a party has validly waived his rights, he cannot later complain of a breach of those rights.

The significance of the waiver in arbitration was recognised by the Departmental Advisory Committee on Arbitration Law: an agreement to arbitrate deprives the party of a 'basic right' to go to court. The need for an agreement to be in writing under section 5 of the Arbitration Act 1996 meets the first of the Court's requirements. As to the wide interpretation of this requirement, see Zambia Steel v Clark \& Eaton [1986] 2 Lloyd's Rep. 225. However, for the purposes of the Act a waiver need not be expressed in writing.

Additional issues arise as to the extent of the waiver that is reflected in the second and third requirements. A party must be 'fully cognisant' of his waiver. Where an agreement to arbitrate refers to the rules of a particular arbitral body, the extent of the waiver will clearly extend to the procedures set out in those rules (for example, to a private hearing). However, the fact that a party agrees to the particular rules does not necessarily imply that the party agrees to the application of those rules (or the substantive law) by an arbitral tribunal in a manner incompatible with all Convention rights. For example, not only can certain basic substantive rights not be waived, but also it cannot be said that agreement to particular rules waives the right to an independent and impartial tribunal. In this regard, the Convention requires 'minimum guarantees' and retains the notion of 'important public interest'. Accordingly, it cannot be excluded, in theory, that the conduct of the arbitration proceedings may breach Article $6(1)$ as the minimum guarantees have not been effectively waived.

\section{Waiver: the conduct of the arbitration proceedings}

The agreement to arbitrate does not to waive a subsequent (and unforeseen) breach of Article 6(1) during 
the conduct of the arbitration. The issue arises as to whether a failure to object expediently to that breach may constitute a further waiver of Article 6(1) rights. In this regard, section 73 of the Arbitration Act 1996 requires that a party to arbitral proceedings must lodge expediently an objection to the conduct of the proceedings, failing which the party may not raise that objection later before the tribunal or the Commercial Court. As any alleged breach of Article 6(1) would be characterised as a 'serious irregularity affecting the tribunal, the proceedings or the award' Arbitration Act 1996, section 68 and any alleged breach of substantive Convention rights would be characterised as a 'question of law', Arbitration Act 1996, section 69 objection must be lodged expediently with the arbitrators as a matter of English law.

Furthermore, recent Scottish and English case law on the application of the Act has confirmed any objection to alleged breaches of Convention rights must be raised expediently. The Inner House of the Court of Session considered the issue in Clancy v. Caird, 2000 SLT 546. The question was whether the failure of the defender to object to a temporary judge hearing his case (on the ground of a contravention of Article 6(1)) precluded him from subsequently raising that objection. The court held that the defender had 'tacitly but unequivocally' waived his right to object.

In Times Newspapers Limited $v$ Choudry and Singh, Court of Appeal (Peter Gibson and Mance LLJ and Brown J), 17 December 1999 (unreported), the issue of an alleged absence of impartiality and independence arose before the Court of Appeal. Having heard argument on Convention authorities, the Court of Appeal held that:

'if there had been - or if anyone had conceived that there
could be- any ground for asking the judge to rescue himself,
it could, should and we have no doubt would have been
raised with the judge either on 12 February 1998 , or on
one of the subsequent occasions when the matter was before
the court for directions leading up to the trial of the further
or, at absolute latest, at the beginning of that further trial.
No such objection was made, despite the representation then
enjoyed by $S$ \& $C$ and Mr. Choudry. If there was any
objection it was thus waived.'

It follows that it is imperative that any party to an arbitration that wishes to raise human rights arguments in an application to the Commercial Court must lodge an objection expeditiously, or risk waiving those arguments.

\section{PRACTICAL EFFECT OF THE APPLICATION OF THE ACT}

The practical effect of the indirect application of the Act on arbitration proceedings is likely to be limited. The limited effect stems from three issues discussed above. of the arbitration agreement or a subsequent failure to object, extinguishes the party's ability to raise human rights complaints. As noted above, to the extent that a waiver has not been validly given or parties object expediently on Convention grounds to particular procedures or substantive decisions, Convention issues will arise for determination. Accordingly, waiver is unlikely to extinguish all challenges under Article 6(1).

Second, the rights guaranteed by Article 6(1) are, to a substantial degree, encapsulated in the general duty of tribunals set out in section 33 of the Arbitration Act 1996 and the discretionary elements in section 34 . In addition, those provisions and the conduct of arbitrations must be construed in accordance with the rules of natural justice. In this respect, only four rights guaranteed by Article 6(1) cannot be found in some form in existing requirements: (i) access to a court, (ii) the right to a public hearing, (iii) the right to the public pronouncement of the decision and (iv) the right to a reasoned judgment. The first of three these rights (and occasionally all four) are customarily waived by the parties in the agreement to arbitrate. The indirect application of the Act may however influence arbitrators to reason their decisions (to the extent that reasons were not previously given) and may found an application to the Commercial Court. Indeed, it is difficult to identify how the Commercial Court can exercise its review in the absence of a reasoned award.

Third, the Convention recognises not only the policy and practical necessity to limit review of arbitral awards by the courts, but also the restricted grounds of appeal, including marginal review of arbitral decisions. Accordingly, the practice of the Commercial Court is unlikely to change dramatically. Arbitrators will retain the discretion required to retain the characteristics of arbitration.

Whilst the effect is likely to be limited, the indirect application of the Act is not without significance. As the Lord Chancellor noted during the passage of the Bill, 'A culture of awareness of human rights will develop...' Both arbitrators and the Commercial Court will be required to test and reconsider procedural and substantive points in the light of the minimum guarantees of the Convention and to interpret English law in accordance with the Act's new interpretative obligation. Recent cases indicate that this evolutionary process can occur, and is occurring; see, for example, Douglas and Others v Hello! supra, $R_{v} A$, supra, and Director General of Fair Trading $v$ The Proprietary Association of Great Britain and another [2000] All ER (D) 2425 in which the test of 'bias' established in $R_{V}$ Gough [1993] AC 646 was reviewed and 'modestly adjusted' (para.86) in the light of Article 6(1). That evolution does not usurp the particular features of arbitration.

William Robinson

Freshfields Bruckhaus Deringer 